\title{
Nutrient Composition, Antioxidant Components and Ascorbic Acid Content Response of Pepper Fruit (Capsicum annuum L.) Cultivars Grown under Salt Stress
}

\author{
Hand Mathias Julien ${ }^{*}$, Nono Giles Vivien², Tonfack Libert Brice ${ }^{3}$, \\ Taffouo Victor Désiré2 ${ }^{2}$ Youmbi Emmanuel ${ }^{3}$ \\ ${ }^{1}$ Department of Biology Science, Faculty of Science, University of Maroua, Maroua, Cameroon \\ ${ }^{2}$ Department of Botany, Faculty of Science, University of Douala, Douala, Cameroon \\ ${ }^{3}$ Unit of Physiology and Plant Improvement, Laboratory of Biotechnology and Environment, Department of Biology and Plant \\ Physiology, Faculty of Science, University of Yaoundé I, Yaoundé, Cameroon \\ Email: *maty_hand@yahoo.fr
}

How to cite this paper: Julien, H.M., Vivien, N.G., Brice, T.L., Désiré, T.V. and Emmanuel, Y. (2021) Nutrient Composition, Antioxidant Components and Ascorbic Acid Content Response of Pepper Fruit (Capsicum annuum L.) Cultivars Grown under Salt Stress. Open Access Library Journal, 8: e6830. https://doi.org/10.4236/oalib.1106830

Received: September 17, 2020

Accepted: March 2, 2021

Published: March 5, 2021

Copyright $\odot 2021$ by author(s) and Open Access Library Inc.

This work is licensed under the Creative Commons Attribution International License (CC BY 4.0).

http://creativecommons.org/licenses/by/4.0/

\begin{abstract}
Salinity stress occurs due to the accumulation of high levels of salts in soil, which ultimately leads to the impairment of plant growth and crop loss. Stress tolerance-inducing compounds have a remarkable ability to improve growth and minimize the effects of salinity stress without negatively affecting the environment by controlling the activities in plants. The pots were arranged in a complete randomized design with one plant per pot and four replicates per treatment and carried out in 2017 and 2018 to study the influence of four levels of $\mathrm{NaCl}(0,50,100$ and $200 \mathrm{mM})$ on the antioxidant, ascorbic acid, organic and inorganic compounds of three pepper fruits cultivars ("Granada", "Goliath" and "Nobili") at mature stage. The results obtained showed that salinity decreased the mineral content, relative water content, and agro-morphological parameters of pepper fruit. This decrease was accompanied by a significant increase of $\mathrm{Na}$, soluble proteins, proline content, fructose, glucose and antioxidants, including total phenolics and flavonoids, and reduced ascorbic acid and $\beta$-carotene content. However, a varietal difference response to salt stress was observed between the studied varieties. Indeed, the variety Granada is characterized by their vigour in absence as in the presence of salt. Under the studied salinity level there was an enhancement of health-promoting compounds (phenolic compounds, flavonoids, and soluble sugar) synthesis in pepper fruits, with significant changes in other quality parameters. "Granada" was more tolerant and stable in physiological, biochem-
\end{abstract}


ical and agro-morphological traits suggesting that it could be grown in salt-affected soils.

\section{Subject Areas}

Agricultural Science

\section{Keywords}

Agro-Morphological Parameters, Antioxidant, Ions Distribution, Organic Compound, Salinity

\section{Introduction}

Salinity is one of the most important environmental factors that affect the distribution and abundance of plant species. Soil salinization occurs mainly in two ways: high evaporation relative to precipitation in association with weak leaching in soils, and salt accumulation as a result of the use of saline water [1]. It is estimated that about $50 \%$ of the world's land will be saline by the middle of the $21^{\text {st }}$ century [2]. Globally, $20 \%$ of irrigated land and $2.1 \%$ of dry land agriculture suffers from the salt problem and $\mathrm{NaCl}$ is the predominant salt causing salinization [3]. Salinity adversely affects germination, growth, physiology and productivity by reducing the ability of plants to take up water causing foliage damage and even death of the plants, imbalance in osmotic potential; ionic equilibrium and nutrient uptake [4]. Further, it facilitates severe ion toxicity by depositing high concentration of $\mathrm{Na}+$ which causes membrane disorganization, inhibition of cell division and expansion. The influence of salinity and mineral nutrient solution, on productivity, photosynthesis and growth has been studied in different plants [5] [6]. It stated that high levels of $\mathrm{Na}+$ inhibit $\mathrm{K}, \mathrm{Ca}$ and $\mathrm{Mg}$ in leaves, which results in a $\mathrm{K} / \mathrm{Na}$ antagonism and net photosynthesis is affected strongly by $\mathrm{NaCl}$ conditions, which is related directly to the closure of stomata as to low intercellular $\mathrm{CO}_{2}$ levels [7]. To develop saline zones and/or the zones having only brackish water resources, it is important to select tolerant varieties. Salinity imposes stress conditions on crop plants, affects growth and chemical contents and has been shown to limit pepper yield [8]. Salt stress severely inhibits plant growth for two reasons: firstly due to an osmotic or water-deficit effect of salinity and secondly due to a salt-specific or ion excess effect of $\mathrm{NaCl}$. Soils with high levels of salinity have a low water potential zone; consequently, it is difficult for the plant to absorb water and nutrients. In other words saline soils expose plants to osmotic stress [9]. One of the most important consequences of osmotic stress on plants is the production of reactive oxygen species (ROS) in large amounts that followed by oxidative damages, the degradation of proteins, lipids, pigments, and DNA [10]. Plants growing in saline conditions take up harmful ions, especially $\mathrm{Na}^{+}$and $\mathrm{Cl}^{-}$ions. Accumulation of $\mathrm{Na}^{+}$and $\mathrm{Cl}^{-}$ions in large amounts is toxic for the cell, and compounds osmotic stress [9]. These ions disrupt mem- 
brane integrity, cell metabolism, enzyme structure, cell growth, and photosynthesis [11]. Although plants have a variety of ways of withstanding the stress, significant loss of yield occurs [12]. Salt stress is known to negatively affect plant growth at all developmental stages, but sensitivity varies greatly at different stages [13]. Crop production in saline areas largely depends on successful germination, seedling emergence and establishment and efficient reproductive phase [13]. Moreover, as environmental stress it may have a strong influence on the concentration of bioactive compounds of vegetables [14]. Meanwhile, there is an increasing need to produce enough food for the world's growing population [1]. In order to address these challenges to the world's food security, the engineering of plants to create species that tolerate salinity has been considered as a promising strategy.

Pepper (Capsicum annuum L.) is an important agricultural crop, not only because of its economic importance, but also for the nutritional value of its fruits; it is an excellent source of natural colors, vitamin $\mathrm{C}$ and antioxidant compounds important for human health [15]. Pepper is a moderately sensitive to salt stress [16], and it is grown under protected glasshouse conditions in temperate regions and in the open field under warm Mediterranean climates. Salinity imposes stress conditions on crop plants [17] and affects growth and chemical contents and has been shown to limit pepper yield [8]. Salt stress severely inhibits plant growth for two reasons: first by an osmotic or water-deficit effect of salinity and second by a salt-specific or ion excess effect of $\mathrm{NaCl}$. Moreover, plants subject to salinity stress conditions produce cytotoxic activated oxygen that can seriously disrupt normal metabolism, through oxidative damage of lipids, proteins, and nucleic acids [18]. To defend against such oxidants, plants have evolved specific protective mechanisms, involving antioxidant molecules and enzymes that protect against the potentially-cytotoxic species of activated oxygen. In case of high salinity, oxidative stress occurs due to closure of stomata, interruption of photosynthetic electron transport and disruption of cellular membrane integrity and antioxidative defense systems of plants start work against oxidative damage. The antioxidants include non-enzymatic ones, such as vitamin E, vitamin C, glutathione and carotenoid ( $\beta$-carotene and zeaxanthin), and enzymes such as superoxide dismutase and catalase [19].

The objective of this study was to investigate the effect of $\mathrm{NaCl}$ treatment on nutrient composition, antioxidant components, ascorbic acid content, and agro-morphological parameters of three varieties of pepper fruit (Capsicum annuum L.) in order to better understand their differences on salt stress tolerance and select tolerant varieties which could be cultivated in arid, semi-arid and coastal saline soils.

\section{Materials and Methods}

\subsection{Plant Materials}

Pepper (Capsicum annuum L.) is especially productive in warm and dry climates 
than $C$. frutescens which can tolerate most climates. It also displays a greater resistance to disease and insects, especially to the tobacco mosaic virus. Capsaicinoids chemicals and antioxidants such as carotenoïds provide the distinctive tastes in $C$. annuun variants. The fruit are berries that may be green, yellow or red when ripe. The mature green stage is ideal to acquire maximum pungency due to capsaicinoids, whereas peppers at red ripe stage are best sources of ascorbic acid and dried fruits contain higher levels of total carotenoids [20]. Hot peppers are used in medicine as well as food in Africa. Seeds of three pepper cultivars ("Granada", "Goliath" and "Nobili"), provided by the breeding program of the Agronomic Institute for Research and Development of Cameroon were used in the study. These varieties were chosen for their socio-economic rank and resistance to the tobacco mosaic virus.

\subsection{Plant Growth Conditions and Salt Treatments}

The present work was performed in the greenhouse of the Faculty of Science at University of Douala, Cameroon, from September 2017 to August 2018. The seeds were surface sterilized with $3 \%$ sodium hypochlorite for $20 \mathrm{~min}$ and washed four times with deionized water. One-month-old pepper seedlings were transplanted into $10-\mathrm{L}$ plastic pots filled with $5 \mathrm{~kg}$ of sterilized sand. The pots were arranged in a complete randomized design with one plant per pot and four replicates per treatment. All plants were fertilized daily with a modified nutrient solution (in $\mathrm{g} \cdot \mathrm{L}^{-1}$ ): $150 \mathrm{~g} \mathrm{Ca}\left(\mathrm{NO}_{3}\right)_{2}, 70 \mathrm{~g} \mathrm{KNO}_{3}, 15 \mathrm{~g}$ Fe-EDTA, $0.14 \mathrm{~g} \mathrm{KH}_{2} \mathrm{PO}_{4}$, $1.60 \mathrm{~g} \mathrm{~K}_{2} \mathrm{SO}_{4}, 11 \mathrm{~g} \mathrm{MgSO}_{4}, 2.5 \mathrm{~g} \mathrm{CaSO}_{4}, 1.18 \mathrm{~g} \mathrm{MnSO}_{4}, 0.16 \mathrm{~g} \mathrm{ZnSO}_{4}, 3.10 \mathrm{~g}$ $\mathrm{H}_{3} \mathrm{BO}_{4}, 0.17 \mathrm{~g} \mathrm{CuSO}_{4}$ and $0.08 \mathrm{~g} \mathrm{MoO}_{3}$ [21]. The $\mathrm{pH}$ of the nutrient solution was adjusted to 7.0 by adding $\mathrm{HNO}_{3} 0.1 \mathrm{mM}$. For the determination of physiological and biochemical responses of pepper cultivars to salt stress, each cultivar was subjected to 0 (control), 50, 100 and $200 \mathrm{mM} \mathrm{NaCl}$. Plants were watered with deionized water every morning. The daily amounts of water added to the pots were the same for all treatments. Throughout the growth period, average day/night temperatures in the greenhouse were $26^{\circ} \mathrm{C} / 20^{\circ} \mathrm{C}$ and the relative air humidity averaged $68.5 \%$.

\subsection{Plant Measurements}

Plant samples were harvested after 4 months culture under salt stress, fruits were collected. The tissues (fruits) were dried for $24 \mathrm{~h}$ at $105^{\circ} \mathrm{C}$ [22]. The dry samples were weighted. Ninety days after sowing, samples from each treatment were collected to determine agro-morphological characters (number of fruit per plant, fresh fruit weight of fruit, dry fruit weight, thickness of fruit, fruit length, fruit diameter), organic components (total soluble proteins, proline, fructose, glucose), inorganic components ( $\mathrm{Na}, \mathrm{K}, \mathrm{Ca}, \mathrm{Mg}, \mathrm{P}, \mathrm{S}, \mathrm{Zn}, \mathrm{Cu}, \mathrm{Mn}, \mathrm{Fe}$ content, $\mathrm{K} / \mathrm{Na}, \mathrm{Ca} / \mathrm{Na}, \mathrm{Mg} / \mathrm{Na}$ ), relative water content, antioxidant levels (total flavonoid content, total phenolic content, ascorbic acid, $\beta$-carotene content) in three pepper fruit cultivars. 


\section{Agromorphological characters}

90 days after transplanting, the fresh fruit weight (FFW) and dry fruit weight (DFW) were determined. The number of fruit per plant, the fruit length and diameter were measured [23].

\section{Total soluble proteins}

Protein content was determined by Bradford's method [24]. Briefly, appropriate volume (from $0-100 \mu \mathrm{l}$ ) of sample was aliquoted into a tube and the total volume was adjusted to $100 \mu \mathrm{l}$ with distilled water. A $1 \mathrm{ml}$ of Bradford working solution was added to each sample well. Then the mixture was thoroughly mixed by vortex mixer. After left for $2 \mathrm{~min}$, the absorbance was read at $595 \mathrm{~nm}$. The standard curve was established by replacing the sample portions in the tubes with proper serial dilutions of bovine serum albumin.

\section{Free proline}

Free proline was determined in $95 \%$ ethanol extracts from fruits. Samples of $0.5 \mathrm{~g}$ of tissues freshly harvested were crushed in $5 \mathrm{ml} 95 \%$ (v/v) ethanol. The insoluble fraction of the extract was washed twice with $5 \mathrm{ml}$ of $70 \%$ ethanol. All soluble fractions were centrifuged at $3500 \times \mathrm{g}$ for $10 \mathrm{~min}$. The supernatants were collected and stored at $4^{\circ} \mathrm{C}$ for proline determination [25]. The free proline content was measured [26].

\section{Total soluble sugar}

Glucose and fructose were extracted from pepper fruit homogenate aliquots according to the protocol described in [27], and then quantified enzymatically [28].

\section{Minerals}

$\mathrm{P}, \mathrm{K}, \mathrm{Ca}, \mathrm{Mg}, \mathrm{S}$ and $\mathrm{Na}$ contents in the fruit tissue of the plants were evaluated in dry, ground, and digested samples in a CEM microwave oven [29]. P was determined by colorimetry; sodium and potassium by flame photometry; copper determination was carried out by means of mass spectrometry with source of plasma connected by induction (ICP-MS), by means of a Hewlett Packard 4500 series; calcium and magnesium by atomic absorption spectrometry and sulfur by turbidimetry of barium sulfate [30]. Iron, zinc and manganese contents were determined by method reported in [31]. Fruit of pepper was dry ashed at $450^{\circ} \mathrm{C}$ for 2 hours and digested on heat cave with $10 \mathrm{ml} \mathrm{HNO}_{3} 1 \mathrm{M}$. The solution was filtrated and adjusted at $100 \mathrm{ml}$ with $\mathrm{HNO}_{3}$ at $1 / 100$ and analyzed with an atomic absorption spectrophotometer (Rayleigh, WFX-100).

\section{Relative water content}

The relative water content (RWC) in fruits was recorded according to the formula as follows: $\mathrm{RWC}=(\mathrm{FFW}-\mathrm{FDW}) /(\mathrm{TW}-\mathrm{FDW}) \times 100$, where FFW is fresh weight, FDW is dry weight, and TW is turgid weight [32].

\section{Total flavonoid content}

FLA content of crude extract was determined by the aluminium chloride colorimetric method [33]. $50 \mu \mathrm{L}$ of crude extract $(1 \mathrm{mg} / \mathrm{mL}$ ethanol) were made up to $1 \mathrm{~mL}$ with methanol, mixed with $4 \mathrm{~mL}$ of distilled water and then $0.3 \mathrm{~mL}$ of 
$5 \% \mathrm{NaNO}_{2}$ solution; $0.3 \mathrm{~mL}$ of $10 \% \mathrm{AlCl}_{3}$ solution was added after $5 \mathrm{~min}$ of incubation, and the mixture was allowed to stand for $6 \mathrm{~min}$. Then, $2 \mathrm{~mL}$ of 1 $\mathrm{mol} / \mathrm{L} \mathrm{NaOH}$ solution were added, and the final volume of the mixture was brought to $10 \mathrm{~mL}$ with double-distilled water. The mixture was allowed to stand for $15 \mathrm{~min}$, and absorbance was recorded on spectrophotometer (Pharmaspec UV-1700 model) at $510 \mathrm{~nm}$ wavelength. FLA content was calculated from a rutin calibration curve, and the result was expressed as g rutin equivalent per $g$ dry weight.

\section{Total phenolic content}

TP content of the extract was determined by the Folin Ciocalteu method [34]. Subsamples $(1 \mathrm{~g})$ of fresh fruits were ground at $4^{\circ} \mathrm{C}$ in $3 \mathrm{~mL}$ of $0.1 \mathrm{~N} \mathrm{HCl}$. After incubation to $4^{\circ} \mathrm{C}$ for $20 \mathrm{~min}$, the homogenate was centrifuged at $6000 \mathrm{~g}$ for 40 min. The supernatant was collected, the pellet re-suspended in $3 \mathrm{~mL}$ of $0.1 \mathrm{~N}$ $\mathrm{HCl}$ and centrifuged as previously. The two supernatant are mixed and constitute the crude extract of soluble phenol. The reaction mixture containing $15 \mu \mathrm{L}$ of extract, $100 \mu \mathrm{L}$ Folin-Ciocalteu reagents, $0.5 \mathrm{~mL}$ of $20 \% \mathrm{Na}_{2} \mathrm{CO}_{3}$ was incubated at $40^{\circ} \mathrm{C}$ for $20 \mathrm{~min}$ and absorbance read at $720 \mathrm{~nm}$ wavelength with a spectrophotometer (Pharmaspec UV-1700 model). A standard curve was established using chlorogenic acid. TP content was expressed as mg g-1 fresh weight.

\section{Ascorbic acid content}

For estimation of ascorbic acid content (ASA), $1 \mathrm{~g}$ of frozen fruit tissues was homogenised in $5 \mathrm{~mL}$ of ice-cold $6 \% \mathrm{~m}$-phosphoric acid (pH 2.8) containing 1 $\mathrm{mM}$ EDTA [35]. The homogenate was centrifuged at 20,000 $\times \mathrm{g}$ for $15 \mathrm{~min}$ at $4^{\circ} \mathrm{C}$. The supernatant was filtered through a $30-\mu \mathrm{m}$ syringe filter, and $50 \mu \mathrm{L}$ of the filtrate was analyzed using an HPLC system (PerkinElmer series $200 \mathrm{LC}$ and UV/VIS detector 200 LC, USA) equipped with a 5 - $\mu$ m column (Spheri-5 RP-18; $220 \times 4.6 \mathrm{~mm}$; Brownlee) and UV detection at $245 \mathrm{~nm}$ with $1.0 \mathrm{~mL} / \mathrm{min}$ water ( $\mathrm{pH} 2.2)$ as the mobile phase, run isocratically [36].

\section{B-carotene content}

$\beta$-carotene was extracted by grinding fruit tissues in a solution of $100 \%$ acetone containing $\mathrm{CaCO}_{3}$ [37]. The extracts were centrifuged at $16,000 \times \mathrm{g}$ for 10 min, and $20 \mu \mathrm{L}$ of the resulting supernatants were used for HPLC analysis, as described by [38] using the previously mentioned HPLC system. Solvent A (acetonitrile, methanol, Tris- $\mathrm{HCl}$ buffer $0.1 \mathrm{M}, \mathrm{pH}$ 8.0, 72:8:3) was run isocratically from 0 to $4 \mathrm{~min}$ followed by a $2.5 \mathrm{~min}$ linear gradient to $100 \%$ solvent $\mathrm{B}$ (methanol, hexane, $4: 1$ ) at a flow rate of $2 \mathrm{~mL} / \mathrm{min}$. The detector was set at $440 \mathrm{~nm}$ for the integration of peak areas after calibration with the external standard.

\section{Experimental design and statistical analysis}

The experiment was conducted as a factorial completely randomized design with four $\mathrm{NaCl}$ treatments and three cultivars in four replications. Data are presented in term of mean ( \pm standard deviation). All data were statistically analysed using Statistica (version 9, Tulsa, OK, USA) and first subjected to analyses of variance (ANOVA). Statistical differences between treatment means were estab- 
lished using the Fisher LSD test at $\mathrm{p}<0.05$.

\section{Results and Discussion}

\subsection{Agro-Morphological Parameters}

According to findings in Table 1, salt stress at 100 and $200 \mathrm{mM} \mathrm{NaCl}$ caused significant decreases in NF, FFW, FDW, TF, FL and FD. The lowest values of these traits were recorded with salt stressed plants at $200 \mathrm{mM}$ concentration, followed by $100 \mathrm{mM}$. In "Granada", "Goliath" and "Nobili" there was a gradual decrease in the fruit length and diameter per plant following the increase in $\mathrm{NaCl}$ salinity. The cultivar "Granada" presented the higher FL $18.86 \mathrm{~cm}$ for control and $14.84 \mathrm{~cm}$ at $200 \mathrm{mM} \mathrm{NaCl}$ and "Goliath" present higher FD, 8.84 to 6.37 $\mathrm{cm}$, when applying the highest of $\mathrm{NaCl}(200 \mathrm{mM})$ (Table 1). The NF decreased linearly with the increase in the salinity, with significant effect on both cultivars (Table 1). The NF of the cultivar "Goliath", 11.41 to 6.89, were higher than those of the cultivar "Nobili", 10.28 to 7.68 and "Granada", 9.81 to 7.23, when applying the highest of $\mathrm{NaCl}(200 \mathrm{mM})$. The cultivar "Granada" showed higher FFW, varied within a range of 45.55 to $37.81 \mathrm{~g}$ respectively to control and $200 \mathrm{mM} \mathrm{NaCl}$ (Table 1). These results were directly related to FDW, which decreased with increasing salinity (Table 1). The TF losses of the cultivars reached $30.06 \%$ in

Table 1. Effect of salinity on some agro-morphological parameters of pepper fruit (Fruit Length, Fruit Diameter, Number of Fruit, Thickness of Fruit, Fresh Fruit Weight and Fruit Dry Weight) at the mature stage (90 DAP).

\begin{tabular}{|c|c|c|c|c|c|c|c|}
\hline Cultivar & $\begin{array}{l}\text { Treatment } \\
(\mathrm{mM} \mathrm{NaCl})\end{array}$ & $\begin{array}{l}\text { Fruit Length } \\
(\mathrm{cm})\end{array}$ & $\begin{array}{l}\text { Fruit Diameter } \\
\qquad(\mathrm{cm})\end{array}$ & Number of Fruit & $\begin{array}{l}\text { Fresh Fruit } \\
\text { Weight (g) }\end{array}$ & $\begin{array}{c}\text { Dry Fruit } \\
\text { Weight (g) }\end{array}$ & $\begin{array}{c}\text { Thickness of } \\
\text { Fruit (mm) }\end{array}$ \\
\hline \multirow{4}{*}{ Granada } & 0 & $18.86 \pm 0.14^{\mathrm{a}}$ & $5.98 \pm 0.09^{\mathrm{b}}$ & $12.82 \pm 0.18^{\mathrm{a}}$ & $45.55 \pm 2.25^{\mathrm{a}}$ & $4.03 \pm 0.07^{\mathrm{a}}$ & $5.82 \pm 0.07^{\mathrm{ab}}$ \\
\hline & 50 & $16.89 \pm 0.18^{\mathrm{ab}}$ & $4.54 \pm 0.11^{\mathrm{b}}$ & $11.22 \pm 0.19^{\mathrm{a}}$ & $43.81 \pm 2.30^{\mathrm{a}}$ & $3.15 \pm 0.04^{\mathrm{a}}$ & $5.78 \pm 0.08^{\mathrm{ab}}$ \\
\hline & 100 & $14.12 \pm 0.15^{\mathrm{b}}$ & $3.77 \pm 0.08^{b c}$ & $8.38 \pm 0.15^{\mathrm{b}}$ & $39.74 \pm 2.01^{b}$ & $1.88 \pm 0.03^{\mathrm{b}}$ & $4.32 \pm 0.06^{\mathrm{b}}$ \\
\hline & 200 & $14.84 \pm 0.11^{\mathrm{b}}$ & $4.08 \pm 0.12^{\mathrm{b}}$ & $7.93 \pm 0.21^{\mathrm{b}}$ & $37.81 \pm 1.88^{\mathrm{b}}$ & $1.61 \pm 0.04^{\mathrm{b}}$ & $4.07 \pm 0.07^{\mathrm{b}}$ \\
\hline \multirow{4}{*}{ Nobili } & 0 & $13.68 \pm 0.09^{b}$ & $7.16 \pm 0.13^{\mathrm{a}}$ & $11.62 \pm 0.22^{\mathrm{a}}$ & $37.67 \pm 1.92^{b}$ & $3.74 \pm 0.05^{\mathrm{a}}$ & $7.27 \pm 0.18^{\mathrm{a}}$ \\
\hline & 50 & $12.16 \pm 0.08^{\mathrm{bc}}$ & $6.87 \pm 0.15^{\mathrm{a}}$ & $10.09 \pm 0.23^{\mathrm{a}}$ & $32.32 \pm 1.89^{\mathrm{d}}$ & $2.04 \pm 0.07^{\mathrm{ab}}$ & $6.66 \pm 0.16^{\mathrm{a}}$ \\
\hline & 100 & $10.64 \pm 0.07^{\mathrm{d}}$ & $4.83 \pm 0.18^{\mathrm{b}}$ & $8.63 \pm 0.21^{b}$ & $35.22 \pm 1.99^{c}$ & $1.05 \pm 0.08^{\mathrm{b}}$ & $5.15 \pm 0.09^{\mathrm{ab}}$ \\
\hline & 200 & $9.88 \pm 0.10^{\mathrm{d}}$ & $4.29 \pm 0.21^{\mathrm{b}}$ & $7.68 \pm 0.24^{\mathrm{b}}$ & $27.43 \pm 1.49^{\mathrm{e}}$ & $0.92 \pm 0.04^{\mathrm{b}}$ & $4.91 \pm 0.11^{\mathrm{b}}$ \\
\hline \multirow{4}{*}{ Goliath } & 0 & $10.77 \pm 0.11^{\mathrm{d}}$ & $8.84 \pm 0.07^{\mathrm{a}}$ & $11.41 \pm 0.2^{\mathrm{a}}$ & $31.27 \pm 1.87^{\mathrm{d}}$ & $2.38 \pm 0.07^{\mathrm{ab}}$ & $7.78 \pm 0.14^{\mathrm{a}}$ \\
\hline & 50 & $8.93 \pm 0.08^{\mathrm{de}}$ & $6.96 \pm 0.09^{\mathrm{a}}$ & $8.23 \pm 0.19^{b}$ & $23.89 \pm 1.66$ & $0.81 \pm 0.02^{\mathrm{b}}$ & $5.89 \pm 0.06^{\mathrm{ab}}$ \\
\hline & 100 & $6.77 \pm 0.07^{\mathrm{e}}$ & $7.11 \pm 0.12^{\mathrm{a}}$ & $7.81 \pm 0.18^{b}$ & $25.65 \pm 1.27^{\mathrm{e}}$ & $0.93 \pm 0.01^{\mathrm{b}}$ & $6.04 \pm 0.09^{\mathrm{a}}$ \\
\hline & 200 & $6.88 \pm 0.06^{\mathrm{e}}$ & $6.37 \pm 0.11^{\mathrm{a}}$ & $6.89 \pm 0.20^{c}$ & $20.33 \pm 1.09^{\mathrm{f}}$ & $0.73 \pm 0.02^{c}$ & $5.60 \pm 0.10^{\mathrm{ab}}$ \\
\hline \multicolumn{8}{|c|}{ Two way ANOVA results } \\
\hline \multicolumn{2}{|c|}{ Cultivar (C) } & * & * & NS & $* *$ & * & NS \\
\hline \multicolumn{2}{|c|}{ Salt treatment $(\mathrm{S})$} & $* *$ & * & * & * & * & * \\
\hline \multicolumn{2}{|c|}{ Interaction $\mathrm{C} \mathrm{X} \mathrm{S}$} & NS & NS & NS & * & NS & NS \\
\hline
\end{tabular}

Values shown are means $(\mathrm{n}=10) \pm \mathrm{SD}$; within columns, means followed by different letter are significantly different $(\mathrm{p}<0.05) .{ }^{* *},{ }^{*}$ significant at $1 \%$ and $5 \%$ probability levels, respectively, NS not significant. 
"Granada", 32.46\% in "Nobili" and 28.02\% in "Goliath" under the highest $\mathrm{NaCl}$ (200 mM). Under salinity stress of $200 \mathrm{mM}$, the best results of NF, FFW, FDW, FL and FD were recorded with "Nobili", followed by "Granada" and "Goliath". Similar results were also reported for tomato [39] and strawberry [40] grown in saline soil. In contrast, several authors reported that FDW significantly increased under saline conditions in a number of horticultural crop species including tomato [41] and cucumber [42]. The reductions of NF, FFW, FDW, TF, FL, FD under salt conditions are possibly due to the adverse impacts of salinity on the growth characteristics and physiological processes such as water uptake, photosynthesis, flowering, and fruition formation, which led to diminished yields. Accordingly, the highest level of salt $(200 \mathrm{mM} \mathrm{NaCl})$ was adversely more effective than the lowest one $(50 \mathrm{mM} \mathrm{NaCl})$. The same trends of salt stress were previously described in faba bean [43] and strawberry plants [44]. Pulp thickness and firmness of pepper fruit are an important variable affecting pepper quality, since it guarantees better postharvest conservation and prevents injury by manipulation. High salinity, above $200 \mathrm{mM} \mathrm{NaCl}$, tended to decrease pulp thickness and fruit firmness. Firmness in pepper fruit has been related to the level of calcium in the fruit [45]. Thus, salinity could reduce fruit pulp thickness and firmness by reducing the availability of calcium in the fruit.

\subsection{Organic Compounds}

The presence of $\mathrm{NaCl}$ resulted in a significant increase in GLU, FRU, SP and PRO contents in fruit of all cultivars compared to untreated plants, thereby playing a major role as osmotic adjustment (Figures 1(a)-(d)). The concentration of free sugars is one of the components along with organic acids that determine fruit flavor attributed to sweetness of pepper fruit. Both FRU and GLU composition differed by level of $\mathrm{NaCl}$ and varieties. The level of fructose across all samples was higher than that of GLU (Figure 1(c) and Figure 1(d)). The contents of FRU and GLU across varieties were higher in pepper produced at 0 $\mathrm{mM} \mathrm{NaCl}$ in "Granada" and "Nobili", at $200 \mathrm{mM}$ "Granada" than those of "Goliath" and other level of $\mathrm{NaCl}$. SP content in plants increased significantly under salt stress in all cultivars compared to untreated plants (Figure 1(b)). These increases were $49.71 \%$ in "Granada", $68.55 \%$ in "Nobili" and 70.23\% in "Goliath" at $200 \mathrm{mM} \mathrm{NaCl}$ in comparison with the control plants. The proline content had markedly accumulated in sweet pepper fruits; the highest concentration was recorded with a salinity at $200 \mathrm{mM} \mathrm{NaCl}$ (47.64\% in "Granada", $86.29 \%$ in "Nobili" and $100.18 \%$ in "Goliath" in comparison to the control plants (Figure 1(a)). The salt tolerant "Granada" accumulated the highest amount of all osmolytes followed by the moderately tolerant "Nobili" and the salt-sensitive "Goliath". [46] observed an increase in protein content when increasing salt concentration. The plants under salinity condition change their metabolism to overcome the changed environmental condition. According to the SP content decreased on account of salinity stress, one of the mechanisms affected by salt stress 


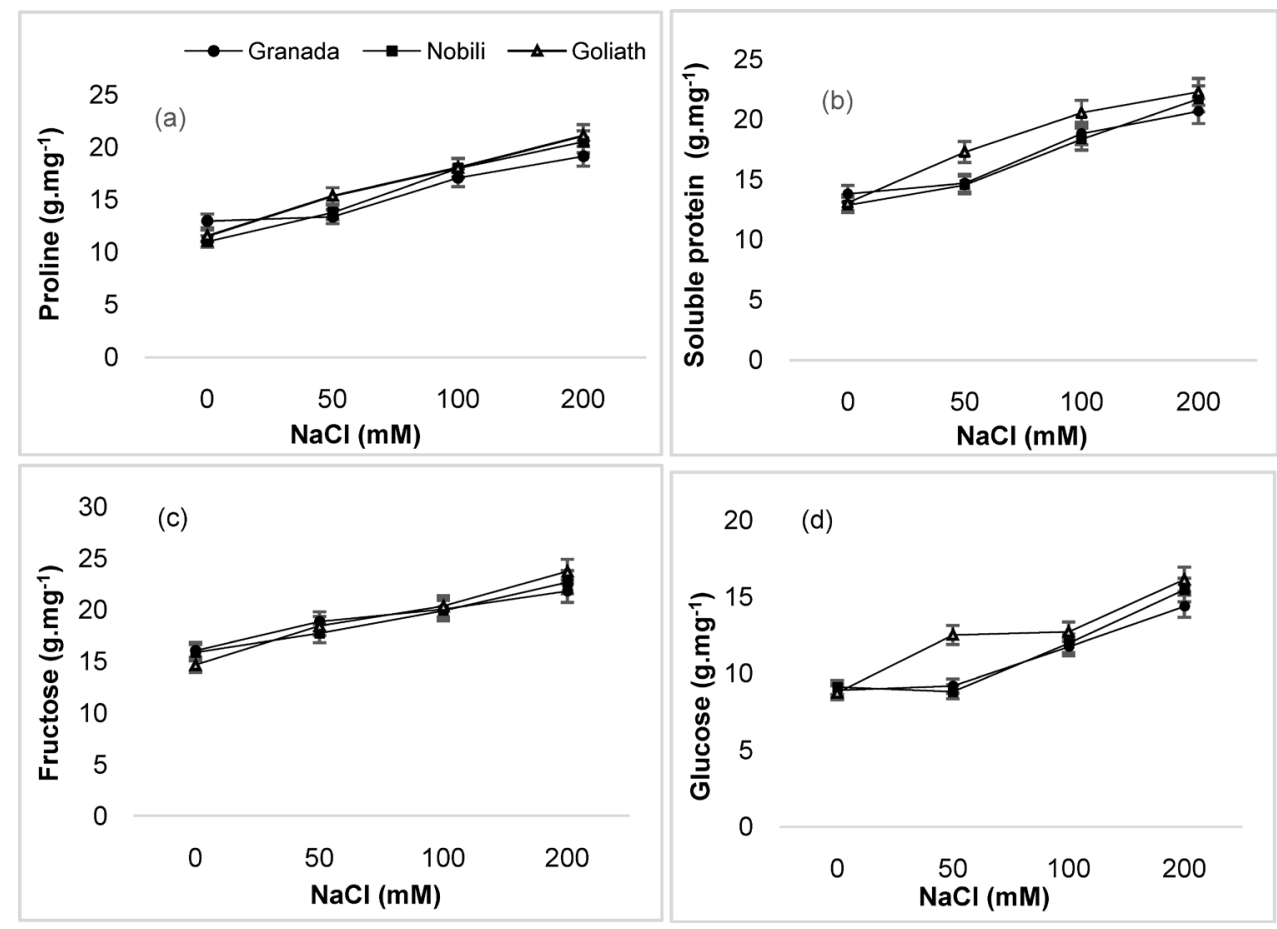

Figure 1. Effect of salt on accumulation of organic compound in pepper cultivars (90 DAP). Proline content (a), soluble proteins (b), fructose content (c) and glucose content (d). Bars are means $(\mathrm{n}=5) \pm \mathrm{SD}$.

in plants was protein synthesis [47]. Proline, which is an amino acid is one such organic solute that plays a major role in this osmotic adjustment [48]. Proline is one of well-known osmoprotectants and its accumulation is widely observed in various organisms under salt stress. The amino-acid may play a role in protecting membranes and proteins against adverse effects of higher concentrations of inorganic ions and temperature extremes. Salinity treatments caused the increased PRO content in pepper plant [48]. One mechanisms utilized by the plants for overcoming the salt stress effects might be via accumulation of compatible osmolytes, such as proline and soluble sugar. Great diversity of free sugars within the Capsicum chinense gene pool [49]. [50] confirmed that tomato (Lycopersicon esculentum. Pepe), total fruit sugar content increased with increased salinity; sucrose played a main role in the regulation of the root osmotic potential followed by K, GLU and $\mathrm{Na}$ this agree with the results [51]. The reduction of sugars content in pepper fruit with salinity could be due to this increase in fruit respiration. The accumulation of osmolyte compounds is often proposed as a solution to overcoming the negative consequences of water deficits in crop production which has been proposed as an adaptive mechanism for drought and salt tolerance. Indeed, osmolyte accumulation in plant cell results in a decrease of the cell osmotic potential and help in the maintenance of water absorption and cell turgor pressure, which might contribute to sustaining physiological processes, such as stomatal opening, photosynthesis and expansion growth [52]. 


\subsection{Antioxidant Compound}

$\mathrm{NaCl}$ effect on fruits TF, TP, CA and ASA concentrations is shown in Figure 2. A significant increase $(\mathrm{p}<0.05)$ was observed for TF and TP at 100 and $200 \mathrm{mM}$ $\mathrm{NaCl}$ in "Granada" and "Nobili" and $50 \mathrm{mM} \mathrm{NaCl}$ in "Goliath". These increases for TF were 30.72\% in "Granada", 46.59\% in "Nobili" and 71.06\% in "Goliath"; and $42.89 \%$ in "Granada", $52.74 \%$ in "Nobili" and 63.13\% in "Goliath" for TP under the highest $\mathrm{NaCl}(200 \mathrm{mM})$ in comparison with the control (Figure 2(a) and Figure 2(b)). Salt effect resulted in a significant decrease for ASA and CA (p $<0.05$ ). The decreases for ASA were 79.83\% in "Granada", $82.71 \%$ in "Nobili" and $82.58 \%$ in "Goliath"; and $27.87 \%$ in "Granada", $30.60 \%$ in "Nobili" and $31.45 \%$ in "Goliath" for CA under the highest $\mathrm{NaCl}(200 \mathrm{mM})$ in comparison with the control (Figure 2(c) and Figure 2(d)). In other vegetables such as amaranth species, [53] observed a decrease of ascorbic acid content with increase of salt concentration. Salinity decreased the ASA content of pepper fruits, and this effect was dependent on the maturity stage [54]. In addition, the possibility for a plant to limit salt accumulation within its tissues triggers differences in the intensity of salinity stress perceived by the plant. Furthermore, it is well known that ASA is an important component of several fruits (tomato, pepper, and strawberry) that reacts with singlet oxygen and other free radicals and suppresses peroxidation [55]. In tomato fruits, the increase of ascorbic acid contents
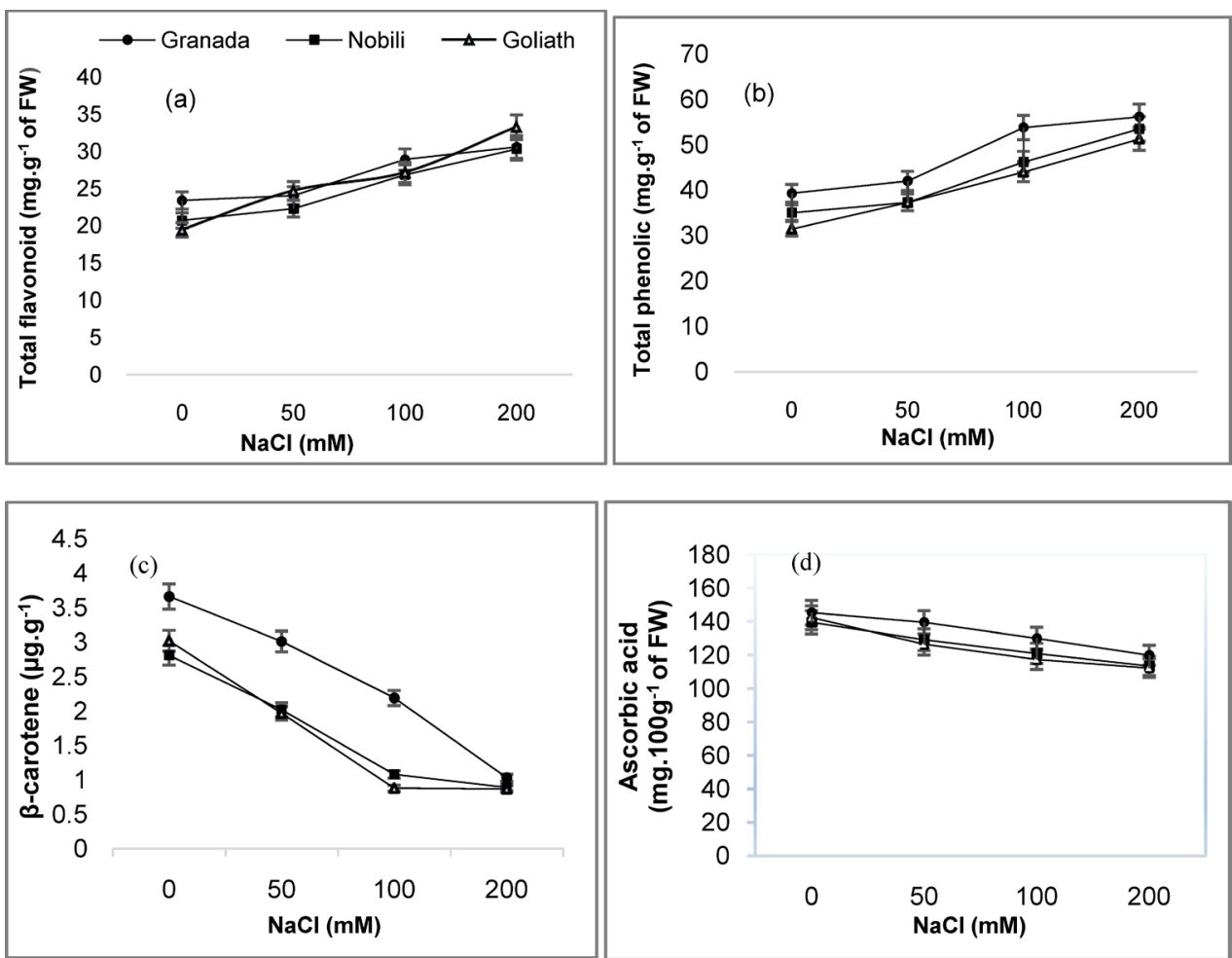

Figure 2. Effect of salt on antioxidant compounds in pepper fruit cultivars at the mature stage (90 DAP). Total flavonoid content (a), total phenolic content (b), $\beta$-carotene content (c) and ascorbic acid content $(d)$. Bars are means $(n=5) \pm$ SD. Means followed by different letter are significantly different $(\mathrm{p}<0.05)$. 
under salt stress was reported [41]. Carotenoids are widely known as powerful natural antioxidants that act as the most efficient singlet oxygen quenchers in vitro among common carotenoids ([56]). In agreement with these data, [57] showed that $\mathrm{CA}$ in tomato fruit was significantly decreased under salt stress. Thus, under the prevailing experimental conditions the decrease in CA contents may relate to the decrease in photosynthetic processes under salinity. A possible explanation would be that salinity may inhibit or upregulate the biosynthetic pathway of carotenoids via inhibition of the genes encoding enzymes related to $\beta$-carotene [58]. Salt stress caused an inhibition in the expression of the gene encoded for lycopene $\beta$-cyclase, the enzyme that converts lycopene to beta carotene [59]. The results on phenol contents are in conformity with the findings in pepper [54] and tomato fruits [60], while it contrasts with those of [61] in other tomato varieties. In addition, [62] reported that adding $\mathrm{NaCl}$ to the nutrient solution did not affect phytonutrients such as flavonoids (quercetin). It is well known that anthocyanins are members of the flavonoid class of plant secondary metabolites that are not usually synthesised in tomato fruits [63]. The increased synthesis of TP, TF contents under saline conditions may reflect some kind of defense against stress conditions since salt stress was accompanied by increased production of reactive oxygen species [64].

\subsection{Fruit Relative Water Content}

Fruit RWC of pepper cultivars at different salinity levels is depicted in Figure 3. There are significant differences between cultivars. A significant decrease in RWC was found at high salinity level $(200 \mathrm{mM})$ in all cultivars compared with control. This decrease may be due to the reduction in water uptake [65] and/or its harmful effect on cell wall structure [66]. The ameliorative effects of these treatments on RWC could be due to the increase in osmoregulators, as well as to osmotic adjustment in plant cells [67] [68]. So, increasing $\mathrm{NaCl}$ salinity concentration tended to reduce the absorption of water leading to a drop in water content, the inhibitory effect of $\mathrm{NaCl}$ on growth parameters could be attributed to the osmotic effect of $\mathrm{NaCl}$ salinity, in addition, the changes in water status under $\mathrm{NaCl}$ stress may cause a reduction in meristem activity as well as cell elongation [48].

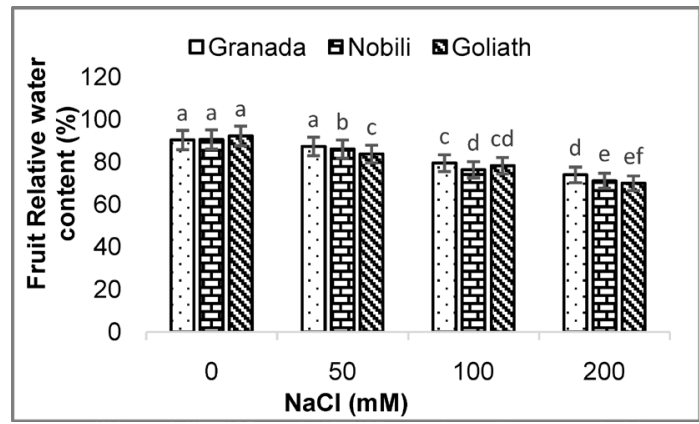

Figure 3. Effect of salt on fruit relative water content in pepper varieties at vegetative mature (90 DAP). Bars are means $(n=5) \pm$ SD Means followed by different letter are significantly different $(\mathrm{p}<0.05)$. 


\subsection{Minerals}

Pepper fruit contains many essential minerals. Most minerals showed variation among the 03 pepper varieties at the different levels of $\mathrm{NaCl}$. Salt treatments differently affected the fruit contents of $\mathrm{P}, \mathrm{Na}, \mathrm{Mg}, \mathrm{Ca}, \mathrm{S}, \mathrm{Fe}, \mathrm{Cu}, \mathrm{Zn}$ and $\mathrm{Mn}$, depending on the genotype (Table 2(a) and Table 2(b)). The main effect of $\mathrm{NaCl}$ on fruit $\mathrm{Na}$ concentrations of plants under salt stress showed significant increases as compared to control plants (Table 2(a)). The highest Na concentrations $(11.22 \mathrm{mg}$ on $100 \mathrm{~g}$ ) were detected in "Goliath" cultivar while the lowest (10.62 $\mathrm{mg}$ on $100 \mathrm{~g}$ ) were recorded in "Granada" at $200 \mathrm{mM} \mathrm{NaCl}$ (Table 2(a)). In this study, $\mathrm{K}, \mathrm{Ca}, \mathrm{P}, \mathrm{Mn}, \mathrm{S}, \mathrm{Cu}, \mathrm{Fe}, \mathrm{Zn}$ and $\mathrm{Mg}$ concentrations were significantly reduced with increasing salinity in all cultivars (Table 2(a) and Table $2(\mathrm{~b})$ ). $\mathrm{K}$ is the most abundant mineral, followed by $\mathrm{P}, \mathrm{Mg}, \mathrm{Ca}, \mathrm{S}, \mathrm{Fe}, \mathrm{Cu}, \mathrm{Zn}$ and $\mathrm{Mn}$. The levels of each mineral across four levels of $\mathrm{NaCl}$ showed a high (significant) variation, indicating these compounds are strongly influenced by salinity. The Ca, $\mathrm{Mg}, \mathrm{Na}, \mathrm{Cu}, \mathrm{Fe}, \mathrm{P}, \mathrm{S}, \mathrm{Zn}, \mathrm{Mn}, \mathrm{K}$ content decreased significantly between 100 and $200 \mathrm{mM} \mathrm{NaCl}$ in "Granada" and "Nobili" cultivars and $50 \mathrm{mM} \mathrm{NaCl}$ in "Goliath" cultivar (Table 2(a) and Table 2(b)). According to the analysis of variance

Table 2. (A) Effect of salt stress on ions concentrations ( $\mathrm{mg}$ on $100 \mathrm{~g}$ of fresh weight) of pepper fruit cultivars at mature stage (90 DAP); (b) Effect of salt stress on ions concentrations ( $\mu \mathrm{g}$ on $100 \mathrm{~g}$ of fresh weight) of pepper fruit cultivars at mature stage (90 DAP).

(a)

\begin{tabular}{|c|c|c|c|c|c|c|c|}
\hline Cultivar & $\begin{array}{l}\text { Treatment } \\
(\mathrm{mM} \mathrm{NaCl})\end{array}$ & $\mathrm{Na}$ & $\mathrm{K}$ & $\mathrm{Ca}$ & $\mathrm{Mg}$ & $\mathbf{P}$ & $S$ \\
\hline \multirow{4}{*}{ Granada } & 0 & $4.88 \pm 0.01^{\mathrm{bc}}$ & $263.71 \pm 2.43^{\mathrm{a}}$ & $12.89 \pm 0.21^{\mathrm{a}}$ & $16.81 \pm 0.34^{\mathrm{a}}$ & $36.81 \pm 0.39^{\mathrm{a}}$ & $12.39 \pm 0.31^{\mathrm{a}}$ \\
\hline & 50 & $5.37 \pm 0.04^{\mathrm{b}}$ & $257.57 \pm 2.47^{\mathrm{b}}$ & $13.97 \pm 0.23^{\mathrm{a}}$ & $15.12 \pm 0.37^{\mathrm{a}}$ & $32.34 \pm 0.41^{\mathrm{b}}$ & $10.86 \pm 0.29^{\mathrm{a}}$ \\
\hline & 100 & $8.14 \pm 0.07^{\mathrm{a}}$ & $222.72 \pm 2.49^{\mathrm{e}}$ & $11.39 \pm 0.19^{\mathrm{a}}$ & $13.99 \pm 0.24^{\mathrm{ab}}$ & $29.33 \pm 0.44^{b c}$ & $11.53 \pm 0.25^{\mathrm{a}}$ \\
\hline & 200 & $10.62 \pm 0.08^{\mathrm{a}}$ & $201.26 \pm 1.83^{\mathrm{f}}$ & $11.77 \pm 0.25^{\mathrm{a}}$ & $11.30 \pm 0.42^{\mathrm{b}}$ & $28.59 \pm 0.42^{c}$ & $8.63 \pm 0.23^{b}$ \\
\hline \multirow{4}{*}{ Nobili } & 0 & $5.39 \pm 0.03^{\mathrm{b}}$ & $243.19 \pm 2.39^{\mathrm{d}}$ & $13.27 \pm 0125^{\mathrm{a}}$ & $15.57 \pm 0.39^{\mathrm{a}}$ & $33.53 \pm 0.38^{\mathrm{ab}}$ & $11.69 \pm 0.19^{\mathrm{a}}$ \\
\hline & 50 & $6.46 \pm 0.05^{\mathrm{b}}$ & $221.47 \pm 2.42^{\mathrm{e}}$ & $10.82 \pm 0.26^{\mathrm{ab}}$ & $16.19 \pm 0.36^{\mathrm{a}}$ & $34.80 \pm 0.36^{\mathrm{a}}$ & $9.31 \pm 0.18^{\mathrm{ab}}$ \\
\hline & 100 & $8.80 \pm 0.06^{\mathrm{a}}$ & $205.79 \pm 3.44^{\mathrm{f}}$ & $11.43 \pm 0.19^{\mathrm{a}}$ & $12.82 \pm 0.41^{\mathrm{b}}$ & $31.09 \pm 0.32^{\mathrm{b}}$ & $7.62 \pm 0.21^{\mathrm{b}}$ \\
\hline & 200 & $10.88 \pm 0.09^{\mathrm{a}}$ & $190.15 \pm 2.51^{\mathrm{g}}$ & $9.93 \pm 0.22^{c}$ & $10.91 \pm 0.39^{b c}$ & $27.15 \pm 0.38^{c}$ & $8.35 \pm 0.18^{b}$ \\
\hline \multirow{4}{*}{ Goliath } & 0 & $5.15 \pm 0.10^{\mathrm{b}}$ & $251.81 \pm 2.42^{\mathrm{c}}$ & $12.81 \pm 0.19^{\mathrm{a}}$ & $14.94 \pm 0.37^{\mathrm{a}}$ & $30.26 \pm 0.42^{\mathrm{bc}}$ & $11.90 \pm 0.23^{\mathrm{a}}$ \\
\hline & 50 & $7.41 \pm 0.08^{\mathrm{ab}}$ & $218.53 \pm 1.44^{\mathrm{e}}$ & $10.26 \pm 0.21^{\mathrm{a}}$ & $11.92 \pm 0.29^{b}$ & $31.42 \pm 0.44^{\mathrm{b}}$ & $8.92 \pm 0.22^{b}$ \\
\hline & 100 & $9.64 \pm 0.07^{\mathrm{a}}$ & $192.45 \pm 2.47^{\mathrm{g}}$ & $8.88 \pm 0.26^{c}$ & $10.28 \pm 0.24^{b c}$ & $23.77 \pm 0.41^{\mathrm{d}}$ & $7.41 \pm 0.21^{\mathrm{b}}$ \\
\hline & 200 & $11.22 \pm 0.09^{\mathrm{a}}$ & $187.68 \pm 1.54^{\mathrm{h}}$ & $8.27 \pm 0.23^{c}$ & $8.12 \pm 0.28^{c}$ & $18.20 \pm 0.39^{\mathrm{e}}$ & $6.67 \pm 0.19^{\mathrm{bc}}$ \\
\hline \multicolumn{8}{|c|}{ Two way ANOVA results } \\
\hline \multicolumn{2}{|c|}{ Cultivar (C) } & * & * & NS & * & * & NS \\
\hline \multicolumn{2}{|c|}{ Salt treatment $(S)$} & $* *$ & * & * & * & * & * \\
\hline \multicolumn{2}{|c|}{ Interaction C X S } & * & * & NS & NS & * & NS \\
\hline
\end{tabular}

Values shown are means $(\mathrm{n}=5) \pm \mathrm{SD}$; within columns, means followed by different letter are significantly different $(\mathrm{p}<0.05) .{ }^{* *},{ }^{*}$ significant at $1 \%$ and $5 \%$ probability levels, respectively, NS not significant. 
(b)

\begin{tabular}{|c|c|c|c|c|c|c|c|c|}
\hline Cultivar & $\begin{array}{l}\text { Treatment } \\
(\mathrm{mM} \mathrm{NaCl})\end{array}$ & $\mathrm{Mn}$ & $\mathrm{Cu}$ & $\mathrm{Fe}$ & $\mathrm{Zn}$ & $\mathrm{K} / \mathrm{Na}$ & $\mathrm{Ca} / \mathrm{Na}$ & $\mathrm{Mg} / \mathrm{Na}$ \\
\hline \multirow{4}{*}{ Granada } & 0 & $201.1 \pm 4.21^{\mathrm{a}}$ & $141.31 \pm 3.28^{\mathrm{b}}$ & $887.66 \pm 5.27^{\mathrm{a}}$ & $572.22 \pm 2.99^{\mathrm{a}}$ & $54.03^{\mathrm{a}}$ & $2.64^{\mathrm{a}}$ & $3.44^{\mathrm{a}}$ \\
\hline & 50 & $198.91 \pm 3.49^{\mathrm{b}}$ & $125.23 \pm 3.09^{\mathrm{d}}$ & $855.32 \pm 4.88^{\mathrm{b}}$ & $537.52 \pm 3.02^{c}$ & $47.96^{\mathrm{b}}$ & $2.60^{\mathrm{a}}$ & $2.81^{\mathrm{a}}$ \\
\hline & 100 & $158.84 \pm 3.38^{\mathrm{e}}$ & $111.12 \pm 2.89^{\mathrm{e}}$ & $818.21 \pm 5.52^{c}$ & $511.23 \pm 3.33^{\mathrm{e}}$ & $27.36^{\mathrm{c}}$ & $1.39^{\mathrm{a}}$ & $1.71^{\mathrm{a}}$ \\
\hline & 200 & $139.71 \pm 3.66^{\mathrm{g}}$ & $107.09 \pm 3.02^{\mathrm{f}}$ & $790.33 \pm 3.29^{f}$ & $499.93 \pm 3.71^{\mathrm{h}}$ & $18.95^{\mathrm{d}}$ & $1.11^{\mathrm{ab}}$ & $1.06^{\mathrm{b}}$ \\
\hline \multirow{4}{*}{ Nobili } & 0 & $177.48 \pm 4.09^{c}$ & $140.25 \pm 3.13^{\mathrm{b}}$ & $801.27 \pm 3.67^{\mathrm{e}}$ & $558.02 \pm 2.96^{\mathrm{b}}$ & $45.11^{\mathrm{b}}$ & $2.46^{\mathrm{a}}$ & $2.88^{\mathrm{a}}$ \\
\hline & 50 & $163.26 \pm 4.27^{\mathrm{d}}$ & $133.20 \pm 2.33^{c}$ & $788.04 \pm 4.21^{\mathrm{g}}$ & $524.71 \pm 3.02^{\mathrm{d}}$ & 34.28 & $1.67^{\mathrm{a}}$ & $2.50^{\mathrm{a}}$ \\
\hline & 100 & $128.87 \pm 4.11^{\mathrm{h}}$ & $127.11 \pm 2.67^{\mathrm{d}}$ & $735.19 \pm 4.44^{\mathrm{h}}$ & $501.88 \pm 3.66^{\mathrm{g}}$ & $23.38^{c}$ & $1.29^{\mathrm{ab}}$ & $1.45^{\mathrm{a}}$ \\
\hline & 200 & $120.73 \pm 3.21^{\mathrm{i}}$ & $110.08 \pm 3.01^{\mathrm{e}}$ & $709.81 \pm 3.89^{j}$ & $488.05 \pm 3.43^{\mathrm{i}}$ & $17.47^{\mathrm{d}}$ & $0.91^{\mathrm{b}}$ & $1.01^{\mathrm{b}}$ \\
\hline \multirow{4}{*}{ Goliath } & 0 & $180.91 \pm 4.55^{\mathrm{c}}$ & $145.29 \pm 3.29^{\mathrm{a}}$ & $813.40 \pm 4.10^{\mathrm{d}}$ & $537.79 \pm 3.61^{c}$ & $48.89^{\mathrm{b}}$ & $2.48^{\mathrm{a}}$ & $2.90^{\mathrm{a}}$ \\
\hline & 50 & $157.75 \pm 3.89^{\mathrm{e}}$ & $133.11 \pm 2.58^{c}$ & $761.11 \pm 3.77^{\mathrm{h}}$ & $509.72 \pm 3.80^{\mathrm{f}}$ & $29.49^{\mathrm{b}}$ & $1.38^{\mathrm{a}}$ & $1.60^{\mathrm{a}}$ \\
\hline & 100 & $143.61 \pm 3.30^{\mathrm{f}}$ & $112.26 \pm 2.17^{\mathrm{e}}$ & $723.78 \pm 3.22^{\mathrm{i}}$ & $480.69 \pm 2.76^{j}$ & $19.96^{\mathrm{d}}$ & $0.92^{\mathrm{b}}$ & $1.06^{\mathrm{b}}$ \\
\hline & 200 & $129.71 \pm 2.99^{\mathrm{h}}$ & $101.07 \pm 2.15^{\mathrm{g}}$ & $694.25 \pm 3.19^{\mathrm{k}}$ & $444.58 \pm 2.88^{\mathrm{k}}$ & $16.72^{\mathrm{de}}$ & $0.73^{\mathrm{bc}}$ & $0.72^{\mathrm{bc}}$ \\
\hline \multicolumn{9}{|c|}{ Two way ANOVA results } \\
\hline \multicolumn{2}{|c|}{ Cultivar (C) } & * & * & * & * & * & NS & * \\
\hline \multicolumn{2}{|c|}{ Salt treatment (S) } & ** & * & $* *$ & * & * & * & * \\
\hline \multicolumn{2}{|c|}{ Interaction C X S } & * & * & * & * & NS & NS & NS \\
\hline
\end{tabular}

Values shown are means $(\mathrm{n}=5) \pm \mathrm{SD}$; within columns, means followed by different letter are significantly different $(\mathrm{p}<0.05) .{ }^{* *},{ }^{*}$ significant at $1 \%$ and $5 \%$ probability levels, respectively, NS not significant.

of the mineral nutrient contents in the sweet pepper fruits, the interaction of the $\mathrm{NaCl}$ with the cultivars affected their $\mathrm{Ca}, \mathrm{P}, \mathrm{Zn}, \mathrm{Fe}, \mathrm{Mn}, \mathrm{S}, \mathrm{K}, \mathrm{Na}$ and $\mathrm{Mg}$ contents (Table 2(a) and Table 2(b)). The cultivars factor had a significant effect for all evaluated nutrients. The fruit $\mathrm{K} / \mathrm{Na}, \mathrm{Ca} / \mathrm{Na}$ and $\mathrm{Mg} / \mathrm{Na}$ ratios were found to be significantly highest in "Granada" and lowest in "Goliath" (Table 2(b)). The content of $\mathrm{K}, \mathrm{Ca}$ and Mg in Zea mays plant decreased significantly under salinity stress, compared with control [69]. The deleterious effects of salinity on plant growth are associated with low water potential of the root medium which causes a water deficit within the plant; toxic effects of ions mainly $\mathrm{Na}^{+}$and $\mathrm{Cl}$; nutritional imbalance caused by reduced nutrient $(\mathrm{K}, \mathrm{S}, \mathrm{P}, \mathrm{Mg}, \mathrm{Cu}, \mathrm{Fe}, \mathrm{Ca}, \mathrm{Mn}$ and $\mathrm{Zn}$ ) uptake and/or transport to the shoot. Salinity mainly causes both hyper-osmotic stress and hyper-ionic toxic effects and the consequence can be plant demise [70]. The contents of $\mathrm{K}$ in the fruit tissues decreased with increasing salinity for all varieties, confirming the effect of salt stress by the high concentration of $\mathrm{Na}$ [71]. Potassium may play a role in the synthesis of endogenous plant hormones [72]. Despite its obvious importance, the low mobility of $\mathrm{Ca}^{2+}$ make the rates of its uptake and distribution limiting processes for many key plant functions. Furthermore, the general lack of recognition of the limiting role of $\mathrm{Ca}^{2+}$ is due in part to the fact that some important plant functions are controlled by changes in very small physiologically active pools of $\mathrm{Ca}^{2+}$ within the 
cytoplasm. As such, whole-leaf $\mathrm{Ca}^{2+}$ levels might not reflect any potential limitations [73]. [74] found that the $\mathrm{P}$ content in tomato (Lycopersicon peruvianum L.) plant decreased was increased $\mathrm{NaCl}$ at $150 \mathrm{mM}$. Decreased $\mathrm{P}$ contents due to increasing salinity were caused probably by the high levels of the $\mathrm{Cl}$ ion, which can have antagonistic interactions with phosphorus [75], however, there is no clear evidence of the interaction between salinity and changes in $\mathrm{P}$ absorption [71]. Salt stress significantly increased the sodium content of pepper fruit. In agreement with these data, several authors reported that salt stress induced the accumulation of $\mathrm{Na}^{+}$in pepper fruit, and this may also result in an enhancement of oxidative parameters [41]. In this study, $\mathrm{K}, \mathrm{Ca}, \mathrm{Cu}, \mathrm{Mn}, \mathrm{Fe}, \mathrm{Zn}, \mathrm{S}$ and $\mathrm{Mg}$ concentrations were significantly reduced with increasing salinity in all cultivars. It has been reported that salinity affects plant physiology through changes of water and ionic status in the cells because of ionic imbalance due to excessive accumulation of $\mathrm{Na}$ and $\mathrm{Cl}$ and reduced uptake of other mineral nutrients, such as $\mathrm{K}, \mathrm{Ca}$ and $\mathrm{Mg}$ [70]. This could be also attributed to the competition of $\mathrm{Na}$ with the uptake $\mathrm{K}, \mathrm{Ca}, \mathrm{Mg}$ resulting in a $\mathrm{K} / \mathrm{Na}, \mathrm{Ca} / \mathrm{Na}$ and $\mathrm{Mg} / \mathrm{Na}$ antagonism [76]. The fruit $\mathrm{K} / \mathrm{Na}, \mathrm{Ca} / \mathrm{Na}$ and $\mathrm{Mg} / \mathrm{Na}$ ratios were found to be significantly highest in "Granada" and lowest in "Goliath" (Table 2(b)). The relationship between the degree to which plant tolerate salt stress and their capacity to maintain a high leaf ratio $\mathrm{K} / \mathrm{Na}$ has been noted by several authors [77]. The levels of each mineral across levels of $\mathrm{NaCl}$ showed a high (significant) variation, indicating these compounds are strongly influenced by salinity. Previous studies have shown that amounts of minerals in pepper fruit depend on the ripening stage, agricultural practices, genotype and environmental factors [78] [79].

\section{Conclusion and Recommendations}

Salinity negatively affects pepper organic and inorganic compounds, antioxidant activity and ASA content and yield, while improving fruit quality. Results from this investigation show that mineral nutrients, agro-morphological, osmolytes and antioxidant compounds to salt stress response among pepper varieties exist. The results obtained show that, the increasing within twelve weeks of treatment doses of $\mathrm{NaCl}$, inhibited all agro-morphological parameters, acid ascorbic, $\beta$-carotene and inorganic compound ( $\mathrm{Cu}, \mathrm{P}, \mathrm{Mn}, \mathrm{S}, \mathrm{Fe}, \mathrm{K}, \mathrm{Zn}, \mathrm{Ca}$ and $\mathrm{Mg}$ ) in fruit from $50 \mathrm{mM} \mathrm{NaCl}$ for Goliath variety and from 100 to $200 \mathrm{mM} \mathrm{NaCl}$, for Granada and Nobili varieties and the total flavonoid, phenolic, fructose, glucose, proline, soluble protein and $\mathrm{Na}+$ significant accumulation in the fruits. The good behaviour of Granada variety in the face of salinity can be considered for their use to better enhance the Sahelian and coastal areas.

\section{Acknowledgements}

The authors thank Dr. ADAMOU and Dr. FOKOM of the Biotechnology Center of Nkolbisson for their excellent technical assistance. This work was not financing. 


\section{Conflicts of Interest}

The authors declare no conflicts of interest regarding the publication of this paper.

\section{References}

[1] Singh, A. (2015) Soil Salinization and Waterlogging: A Threat to Environment and Agricultural Sustainability. Ecological Indicators, 57, 128-130. https://doi.org/10.1016/j.ecolind.2015.04.027

[2] Mahajan, S. and Tuteja, N. (2005) Cold, Salinity and Drought Stresses: An Overview. Archives of Biochemistry and Biophysics, 444, 139-158.

https://doi.org/10.1016/j.abb.2005.10.018

[3] Munns, R. and Tester, M. (2008) Mechanisms of Salinity Tolerance. Annual Review of Plant Biology, 59, 651-681. https://doi.org/10.1146/annurev.arplant.59.032607.092911

[4] Niu, X., Bressan, R.A., Hasegwa, P.M. and Pardo, J.M. (1995) Ion Homeostasis in $\mathrm{NaCl}$ Stress Environments. Plant Physiology, 109, 735-742.

https://doi.org/10.1104/pp.109.3.735

[5] Li, N., Chen, S., Zhou, X., Li, C., Shao, J., Wang, R., Fritz, E. and Hüttemannn Polle, A. (2008) Effect of $\mathrm{NaCl}$ on Photosynthesis, Salt Accumulation, and Compartmentation in Two Mangrove Species, Kandelia candel and Bruguiera gymnorrhiza. Aquatic Botany, 88, 303-310. https://doi.org/10.1016/j.aquabot.2007.12.003

[6] Taffouo, V.D., Wamba, F.O., Youmbi, E., Nono, G.N. and Akoa, A. (2010) Growth, Yield, Water Status and Ionic Distribution Response of Three Bambara Groundnut (Vigna subterranean L. verdc.) Landraces Grown under Saline Conditions. International Journal of Botany, 6, 53-58. https://doi.org/10.3923/ijb.2010.53.58

[7] Turan, M.A., Turkmen, N. and Taban, N. (2007) Effect of $\mathrm{NaCl}$ on Stomacal Resistance and Proline, Chlorophyll, $\mathrm{Na}, \mathrm{Cl}$ and $\mathrm{K}$ Concentrations of Lentil Plants. Journal of Agronomy, 6, 378-381. https://doi.org/10.3923/ja.2007.378.381

[8] Paridam, A.K. and Das, A.B. (2005) Salt Tolerance and Salinity Effects on Plants: A Review. Ecotoxicology and Environmental Safety, 60, 324-349. https://doi.org/10.1016/j.ecoenv.2004.06.010

[9] Agarwal, P.K., Shukla, P.S., Gupta, K. and Jha, B. (2013) Bioengineering for Salinity Tolerance in Plants: State of the Art. Molecular Biotechnology, 54, 102-123. https://doi.org/10.1007/s12033-012-9538-3

[10] Das, K. and Roychoudhury, A. (2014) Reactive Oxygen Species (ROS) and Response of Antioxidants as ROS-Scavengers during Environmental Stress in Plants. Frontiers in Environmental Science, 2, 53. https://doi.org/10.3389/fenvs.2014.00053

[11] Ghosh, D. and Xu, J. (2014) Abiotic Stress Responses in Plant Roots: A Proteomics Perspective. Frontiers in Plant Science, 5, 6. https://doi.org/10.3389/fpls.2014.00006

[12] Deinlein, U., Stephan, A.B., Horie, T., Luo, W., Xu, G. and Schroeder, J.I. (2014) Plant Salt-Tolerance Mechanisms. Trends in Plant Science, 19, 371-379. https://doi.org/10.1016/j.tplants.2014.02.001

[13] Akinci, I.E., Akinci, S., Yilmaz, K. and Dikici, H. (2004) Response of Eggplant Varieties (Solanum melongena) to Salinity in Germination and Seedling Stages. New Zealand. Journal of Crop Horticultural Science, 32, 193-200. https://doi.org/10.1080/01140671.2004.9514296

[14] Prasad, S.M., Parihar, P. and Singh, V.P. (2014) Effect of Salt Stress on Nutritional 
Value of Vegetables. Biochemistry and Pharmacology, 3, 1000e160. https://doi.org/10.4172/2167-0501.1000e160

[15] Howard, L.R., Talcott, S.T., Brenes, C.S. and Villalon, B. (2000) Changes in Phytochemical and Antioxidant Activity of Selected Pepper Cultivars (Capsicum spp.) as Influenced by Maturity. Journal of Agricultural and Food Chemistry, 48, 1713-1720. https://doi.org/10.1021/jf990916t

[16] Lee, S.K.D. (2006) Hot Pepper Response to Interactive Effects of Salinity and Boron. Plant, Soil and Environment, 52, 227-233. https://doi.org/10.17221/3433-PSE

[17] Hajer, A.S., Malibari, A.A., Al-Zahrani, H.S. and Almaghrabi, O.A. (2006) Responses of Three Tomato Cultivars to Sea Water Salinity 1. Effect of Salinity on the Seedling Growth. African Journal of Biotechnology, 5, 855-861.

[18] Abbaspour, H. (2012) Effects of Salt Stress on Lipid Peroxidation, Antioxidative Enzymes and Proline Accumulation in Pistachio Plants. Journal of Medicinal Plants Research, 6, 526-529.

[19] Whittington, J. and Smith, F.A. (1992) Calcium-Salinity Interactions Affect ion Transport in Chara corallina. Plant, Cell \& Environment, 15, 727-733. https://doi.org/10.1111/j.1365-3040.1992.tb01015.x

[20] Iqbal, Q., Amjad, M., Asi, M.R. and Arino, A. (2013) Characterization of Capsaicinoids and Antioxidant in Hot Pepper as Influenced by Hybrid and Harvesting Stage. Plant Foods for Human Nutrition, 68, 358-363.

https://doi.org/10.1007/s11130-013-0386-5

[21] Hoagland, D.R. and Arnon, D.I. (1950) The Water Culture Method for Growing Plants without Soil. University of California, Baltimore, USA.

[22] Taffouo, V.D., Djiotie, N.L., Kenne, M., Din, N., Priso, J.R., Dibong, S. and Akoa, A. (2008) Effect of Salt Stress on Physiological and Agronomic Characterstics of Three Tropical Cucurbit Species. Journal of Applied Biosciences, 10, 434-441.

[23] Adedeji, O., Taiwo, K.A., Akanbi, C.T. and Ajani, R. (2006) Physiochemical Properties of Four Tomato Cultivars Growing in Nigeria. Journal of Food Process Engineering, 30, 79-86. https://doi.org/10.1111/j.1745-4549.2005.00049.x

[24] Bradford, M.M. (1976) A Rapid and Sensitive Method for the Quantitation of Microgram Quantities of Proteins Utilizing the Principle of Protein-Dye Binding. Analytical Biochemistry, 72, 248-254. https://doi.org/10.1016/0003-2697(76)90527-3

[25] Irigoyen, J.J., Emerich, D.W. and Sanchez-Diaz, M. (1992) Water Stress Induced Changes in Concentrations of Proline and Total Soluble Sugars in Nodulated Alfalfa (Medicago sativa) Plants. Physiologia Plantarum, 84, 55-60. https://doi.org/10.1111/j.1399-3054.1992.tb08764.x

[26] Paquin, R. and Lechasseur, P. (1979) Observations on Measurement Method of Free Proline in Extracts from Plants. Canadian Journal of Botany, 57, 1851-1854. https://doi.org/10.1139/b79-233

[27] Hostettler, C., Kölling, K., Santelia, D., Streb, S., Kötting, O. and Zeeman, S.C. (2011) Analysis of Starch Metabolism in Chloroplasts. In: Jarvis, R., Ed., Methods in Molecular Biology, Vol. 775, Humana Press, Totowa, NJ, 387-410. https://doi.org/10.1007/978-1-61779-237-3 21

[28] Thalmann, M., Pazmino, D., Seung, D., Horrer, D., Nigro, A. and Meier, T. (2016) Regulation of Leaf Starch Degradation by Abscisic Acid Is Important for Osmotic Stress Tolerance in Plants. The Plant Cell, 28, 1860-1878.

https://doi.org/10.1105/tpc.16.00143 
[29] Abreu, C.A., et al. (1995) Comparação de métodos de análise para avaliar a disponibilidade de metais emsolos. Revista Brasileira de Ciência do Solo, Campinas, 19, 463-468.

[30] Malavolta, E., Vitti, G.C. and Oliveira, S.A. (1997) Avaliação do estado nutricional das plantas: princípios e aplicações. 2nd Edition, POTAFOS, Piracicaba, SP, 319 p.

[31] Pauwels, J.M., Van Ranst, E., Verloo, M. and Mvondo, Z.A. (1992) Analysis Methods of Major Plants Elements. Pedology Laboratory Manual: Methods of Plants and Soil Analysis. Stock Management Equipment of Worms and Chemical Equipment. Publica Agricol. 28, AGCD, Brussels.

[32] Sánchez, F.J., de Andrés, E.F., Tenorio, J.L. and Ayerbe, L. (2004) Growth of Epicotyls, Turgor Maintenance and Osmotic Adjustment in Pea Plants (Pisum sativum L.) Subjected to Water Stress. Field Crops Research, 86, 81-90. https://doi.org/10.1016/S0378-4290(03)00121-7

[33] Chang, C.C., Yang, M.H., Wen, H.M. and Chern, J.C. (2002) Estimation of Total Flavonoid Content in Propolis by Two Complementary Colorimetric Methods. Journal of Food Drug Analysis, 10, 178-182. https://doi.org/10.38212/2224-6614.2748

[34] Marigo, G. (1973) On a Fractionation Method and Estimation of the Phenolic Compounds in Plants. Analysis, 2, 106-110.

[35] Gossett, D.R., Millhollon, E.P. and Lucas, M.C. (1994) Antioxidant Response to NaCI Stress in Salt-Tolerant and Salt-Sensitive Cultivars of Cotton. Crop Science, 34, 706-714. https://doi.org/10.2135/cropsci1994.0011183X003400030020x

[36] Gahler, S., Otto, K. and Bohm, V. (2003) Alterations of Vitamin C, Total Phenolics, and Antioxidant Capacity as Affected by Processing Tomatoes to Different Products. Journal of Agricultural and Food Chemistry, 51, 7962-7968. https://doi.org/10.1021/jf034743q

[37] Jung, S. (2004) Variation in Antioxidant Metabolism of Young and Mature Leaves of Arabidopsis thaliana Subjected to Drought. Plant Science, 166, 459-466.

https://doi.org/10.1016/j.plantsci.2003.10.012

[38] Gilmore, A.M. and Yamamoto, H.Y. (1991) Linear Models Relating Xanthophylls and Lumen Acidity to Non-Photochemical Fluorescence Quenching. Evidence That Antheraxanthin Explains Zeaxanthin-Independent Quenching. Photosynthesis Research, 35, 67-78. https://doi.org/10.1007/BF02185412

[39] Saeed, R. and Ahmad, R. (2009) Vegetative Growth of tomato as Affected by the Application of Organic Mulch and Gypsum under Saline Rhizosphere. Pakistan Journal of Botany, 41, 3093-3105.

[40] Khayyat, M., Tafazoli, E., Eshghi, S., Rahemi, M. and Rajaee, S. (2007) Salinity, Supplementary Calcium and Potassium Effects on Fruit Yield and Quality of Strawberry (Fragaria ananassa Duch.). American-Eurasian Journal of Agricultural \& Environmental Sciences, 2, 539-544.

[41] Gautier, H., Lopez-Lauri, F., Massot, C., Murshed, R., Marty, I., Grasselly, D., Keller, C., Sallanon, H. and Genard, M. (2010) Impact of Ripening and Salinity on Tomato Fruit Ascorbate Content and Enzymatic Activities Related to Ascorbate Recycling. Functional Plant Science and Biotechnology, 4, 66-75.

[42] Chartzoulakis, K.S. (1992) Effects of $\mathrm{NaCl}$ Salinity on, Germination, Growth and Yield of Greenhouse Cucumber. Journal of Horticultural Science, 67, 115-119. https://doi.org/10.1080/00221589.1992.11516227

[43] Abdul Qados, A.M.S. (2011) Effect of Salt Stress on Plant Growth and Metabolism of Bean Plant (Vicia faba L.). Journal of the Saudi Society of Agricultural Sciences, 
10, 7 -15. https://doi.org/10.1016/j.jssas.2010.06.002

[44] Yildirim, E., Karlidag, H. and Turan, M. (2009) Mitigation of Salt Stress in Strawberry by Foliar K, Ca and Mg Nutrient Supply. Plant, Soil and Environment, 55, 213-221. https://doi.org/10.17221/383-PSE

[45] Belakbir, A., Rulz, J.M. and Romero, L. (1998) Yield and Fruit Quality of Pepper (Capsicum annuum L.) in Response to Bioregulators. HortScience, 33, 85-87. https://doi.org/10.21273/HORTSCI.33.1.85

[46] Kapoor, K. and Srivastava, A. (2010) Assessment of Salinity Tolerance of Vinga mungo var. Pu-19 Using ex Vitro and in Vitro Methods. Asian Journal of Biotechnology, 2, 73-85. https://doi.org/10.3923/ajbkr.2010.73.85

[47] Ebrahimian, E. and Bybordi, A. (2012) Effect of Salinity, Salicylic Acid, Silicium and Ascorbic Acid on Lipid Peroxidation, Antioxidant Enzyme Activity and Fatty Acid Content of Sunflower. African Journal of Agricultural Research, 7, 3685-3694.

[48] Chookhampaeng, S. (2011) The Effect of Salt Stress on Growth, Chlorophyll Content Proline Content and Antioxidative Enzymes of Pepper (Capsicum Annuum L.) Seedling. European Journal of Scientific Research, 49, 103-109.

[49] Jarret, R.L., Berke, T., Baldwin, E.A. and Antonious, G.F. (2009) Variability for Free Sugars and Organic Acids in Capsicum chinense. Chemistry \& Biodiversity, 6, 138-145. https://doi.org/10.1002/cbdv.200800046

[50] Zhang, P., Senge, M., Yoshiyama, K., Ito, K., Dai, Y. and Zhang, F. (2017) Effects of Low Salinity Stress on Growth, Yield and Water Use Efficiency of Tomato under Soilless Cultivation. Transactions of the Japanese Society of Irrigation, Drainage and Rural Engineering, 85, I_15-I_21.

[51] Eisa, S.S. and Ali, S.H. (2003) Biochemical, Physiological and Morphological Responses of Sugar Beet to Salinization.

[52] Blum, A. (1996) Crop Responses to Drought and the Interpretation of Adaptation. Plant Growth Regulation, 20, 135-148. https://doi.org/10.1007/BF00024010

[53] Ratnakar, A. and Rai, A. (2013) Effect of $\mathrm{NaCl}$ Salinity on $\beta$-Carotene, Thiamine, Riboflavin and Ascorbic Acid Contents in the Leaves of Amaranthus polygamous L. var. Pusa Kirti. Journal of Stress Physiology \& Biochemistry, 9, 187-192.

[54] Navarro, J.M., Flores, P., Garrido, C. and Martínez, V. (2006) Changes in Antioxidant Compounds Content in Different Ripening Stages of Pepper Fruits Affected by Salinity. Food Chemistry, 96, 66-73. https://doi.org/10.1016/j.foodchem.2005.01.057

[55] Dorais, M., Ehret, D.L. and Papadopoulos, A.P. (2008) Tomato (Solanum lycopersicum) Health Components, from the Seed to the Consumer. Phytochemistry Reviews, 7, 231-250. https://doi.org/10.1007/s11101-007-9085-x

[56] Di Mascio, P., Kaiser, S. and Sies, H. (1989) Lycopene as the Most Efficient Biological Carotenoid Single Oxygen Quencher. Archives of Biochemistry and Biophysics, 274, 532-538. https://doi.org/10.1016/0003-9861(89)90467-0

[57] Dorais, M., Turcotte, G., Papadopoulos, A.P., Hao, X. and Gosselin, A. (2000) Control of Tomato Fruit Quality and Flavour by EC and Water Management. Agriculture and Agri-Food Canada, 18-21.

[58] Dumas, Y., Dadomo, M., Di Lucca, G. and Grolier, P. (2003) Effects of Environmental Factors and Agricultural Techniques on Antioxidant Content of Tomatoes. Journal of the Science of Food and Agriculture, 83, 369-382. https://doi.org/10.1002/jsfa.1370

[59] Babu, M.A., Singh, D. and Gothandam, K.M. (2011) Effect of Salt Stress on Expression of Carotenoid Pathway Genes in Tomato. Journal of Stress Physiology \& Bio- 
chemistry, 7, 87-94.

[60] Krauss, S., Schnitzler, W., Grassmann, J. and Woltike, M. (2006) The Influence of Different Electrical Conductivity Values in a Simplified Recirculating Soilless System on Inner and Outer Fruit Quality Characteristics of Tomato. Journal of Agricultural and Food Chemistry, 54, 441-448. https://doi.org/10.1021/jf051930a

[61] Maggio, A., De Pascale, S., Fagnano, M. and Barbieri, G. (2007) Can Salt Stress-Induced Physiological Responses Protect Tomato Crops from Ozone Damages in Mediterranean Environments? European Journal of Agronomy, 26, 454-461. https://doi.org/10.1016/j.eja.2007.01.004

[62] Shi, J., Le, Maguer, M. and Bryan, M. (2002) Functional Foods: Biochemical and Processing Aspects. CRC Press, Boca Raton, FL.

[63] Mes, P.J., Boches, P. and Myers, J.R. (2008) Characterization of Tomatoes Expressing Anthocyanin in the Fruit. Journal of the American Society for Horticultural Science, 133, 262-269. https://doi.org/10.21273/JASHS.133.2.262

[64] Rezazadeh, A., Ghasemnezhad, A., Barani, M. and Telmadarrehei, T. (2012) Effect of Salinity on Phenolic Composition and Antioxidant Activity of Artichoke (Cynara scolymus L.) Leaves. Research Journal of Medicinal Plants, 6, 245-252. https://doi.org/10.3923/rjmp.2012.245.252

[65] Parvin, K., Hasanuzzaman, M., Bhuyan, M.H.M.B., Nahar, K., Mohsin, S.M. and Fujita, M. (2019) Comparative Physiological and Biochemical Changes in Tomato (Solanum lycopersicum L.) under Salt Stress and Recovery: Role of Antioxidant Defense and Glyoxalase Systems. Antioxidants, 8, 350.

https://doi.org/10.3390/antiox8090350

[66] Abdelaal, K.A.A., Hafez, Y.M., El-Afry, M.M., Tantawy, D. and Alshaal, T. (2018) Effect of Some Osmoregulators on Photosynthesis, Lipid Peroxidation, Antioxidative Capacity, and Productivity of Barley (Hordeum vulgare L.) under Water Deficit Stress. Environmental Science and Pollution Research, 25, 30199-30211. https://doi.org/10.1007/s11356-018-3023-x

[67] Kasim, W., AboKassem, E. and Ragab, G. (2017) Ameliorative Effect of Yeast Extract, IAA and Green-Synthesized Nano Zinc Oxide on the Growth of Cu-Stressed Vicia faba Seedlings. Egyptian Journal of Botany, 57, 1-16.

[68] Hafez, E., Omara, A.E.D. and Ahmed, A. (2019) The Coupling Effects of Plant Growth Promoting Rhizobacteria and Salicylic Acid on Physiological Modifications, Yield Traits, and Productivity of Wheat under Water Deficient Conditions. Agrono$m y$, 9, 524. https://doi.org/10.3390/agronomy9090524

[69] Bassuony, F.M., Hassanein, R.A., Baraka, D.M. and Khalil, R.R. (2008) Physiological Effects of Nicotinamide and Ascorbic Acid on Zea mays Plant Grown under Salinity Stress II-Changes in Nitrogen Constituents, Protein Profiles, Protease Enzyme and Certain Inorganic Cations. Australian Journal of Basic and Applied Sciences, 2, 350-359.

[70] Hasegawa, P.M., Bressan, R.A., Zhu, J.K. and Bohnert, H.J. (2000) Plant Cellular and Molecular Responses to High Salinity. Annual Review of Plant Physiology and Plant Molecular Biology, 51, 463-499.

https://doi.org/10.1146/annurev.arplant.51.1.463

[71] Duman, F. (2012) Uptake of Mineral Elements during Abiotic Stress. In: Hamad, P. and Prasad, M.N.V., Eds., Abiotic Stress Response in Plants, Springer, New York, 267-282. https://doi.org/10.1007/978-1-4614-0634-1 15

[72] Haeder, H.E. and Beringer, H. (1981) Influence of Potassium Nutrition and Water Stress on the Content of Abscisic Acid in Grains and Flag Leaves of Wheat during 
Grain Development. Journal of the Science of Food and Agriculture, 32, 552-556. https://doi.org/10.1002/jsfa.2740320605

[73] McLaughlin, S.B. and Wimmer, R. (1999) Transley Review No. 104: Calcium Physiology Terrestrial Ecosystem Processes. New Phytologist, 142, 373-417. https://doi.org/10.1046/j.1469-8137.1999.00420.x

[74] Soltani Nezhad, F., Ehsanpour, A.A. and Hosseini, S.M. (2011) Effect of Salt Stress on Acid Phosphatase Activity and Phosphorus Content of lycopersicon peruvianum L. under in Vitro Culture. Malaysian Applied Biology, 40, 7-11.

[75] Hajiaghaei-Kamrani, M. and Hosseinniya, H. (2013) Effect of Salinity on Nutrient Uptake in Tomato (Lycopersicon esculentum Mill.) in Hydroponic System. International Journal of Agronomy and Plant Production, 4, 2729-2733.

[76] Hosseini, G. and Thengane, R.J. (2007) Salinity Tolerance in Cotton (Gossipium hirsutum L.) Genotypes. International Journal of Botany, 3, 48-55. https://doi.org/10.3923/ijb.2007.48.55

[77] Al-Karaki, G.N. (2000) Growth, Water Use Efficiency, and Sodium and Potassium Acquisition by Tomato Cultivars Grown under Salt Stress. Journal of Plant Nutrition, 23, 1-8. https://doi.org/10.1080/01904160009381992

[78] Guil-Guerrero, J.L., Martinez-Guirado, C., Rebolloso-Fuentes, M.M. and Carrique-Pérez, A. (2006) Nutrient Composition and Antioxydant Activity of 10 Pepper (Capsicum annuum L.) Varieties. European Food Research and Technology, 224, 1-9. https://doi.org/10.1007/s00217-006-0281-5

[79] Pérez-Lopez, A.J., Lope-Nicolas, J.M., Nunez-Delicado, E., Amor, F.M. and Carbonell-Barrachina, A.A. (2007) Effect of Agricultural Practices on Color, Carotenoids Composition and Minerals Contents of Sweet Pepper, cv. Almuden. Journal of Agricultural and Food Chemistry, 55, 8158-8164. https://doi.org/10.1021/jf071534n

\section{Abbreviations}

Calcium-Ca; $\beta$-carotene-CA; chlorophyll-CHL; days after planting-DAP; flavonoids-FLA; magnesium-Mg; Ascorbic acid-ASA; fructose-FRU; glucose-GLU; number of ripe fruit per plant-NF; fruit length-FL; fruit diameter-FD; sodium-Na; zin-Zn; iron-Ir; Manganese-Mn; sulfate-S; phosphorus-P; potassium-K; proline-PRO; relative water content-RWC; fruit dry weight-FDW; fruit fresh weight-FFW; thickness of fruit-TF soluble proteins-SP; total free amino acids content-FAA; copper-Cu; iron-Fe; total phenolic-TP; total soluble sugars-SS 